\title{
NILAI-NILAI PENDIDIKAN MULTIKULTURAL DALAM FILM 'ENTRE LES MURS' PENELITIAN \\ ANALISIS ISI
}

\author{
Amalia Saleh \\ Universitas Negeri Jakarta, Jakarta \\ Email: amalia284@yahoo.fr
}

\begin{abstract}
Abstrak
Penelitian ini bertujuan untuk memahami secara komprehensif nilai-nilai pendidikan multikultural dari James Banks dalam film "Entre les Murs". Penelitian kualitatif ini menggunakan analisis percakapan. Analisis dan interpretasi data menunjukkan bahwa: (1) integrasi isi ditunjukkan dalam film melalui diskusi antar guru, bukan dari kurikulum sekolah; (2) proses konstruksi ilmu pengetahuan ditunjukkan dari metode mengajar; (3) pedagogik kesetaraan antar manusia ditunjukkan dari sikap guru yang memberikan kesempatan bagi siswanya untuk meningkatkan rasa kepercayaan diri, memotivasi siswa, dan memberikan ilmu yang sama tanpa memandang etnis; (4) pengurangan prasangka terlihat dari tingkah laku positif seperti interaksi interpersonal dari para siswa yang menunjukkan usaha untuk mengurangi prasangka, walaupun masih ada prasangka negatif yang terlihat; dan (5) pemberdayaan kebudayaan sekolah terlihat dari program sekolah yang memungkinkan adanya keterlibatan seluruh perangkat sekolah seperti kepala sekolah, guru, siswa, dan orangtua siswa.
\end{abstract}

Kata Kunci: Analisis percakapan, film, multikultural, pendidikan multikultural

\begin{abstract}
The objective of this research is to understand comprehensively the values of multicultural education from James Banks on the film "Entre les Murs". This qualitative research uses conversation analysis. The data analysis and interpretation indicates (1) content integration is shown on the film from the discussions between the teacher; (2) knowledge construction process is shown from the teaching method; (3) equity pedagogy is shown from the teachers who provide opportunities for students to boost their confidence, motivate students, and provide the same education regardless of ethnicity; (4) prejudice reduction is shown in interpersonal interactions between students that indicate an effort of prejudice reduction such as helping each other, even though the negative prejudicefrom the teachers and the students are still shown; (5) empowering school culture and social structure is shown from school programs that enable the involvement of all school stakeholders.
\end{abstract}

Keywords: Conversation analysis, multicultural, multicultural education.

\section{PENDAHULUAN}

"Entre les Murs" atau The Class, adalah film Prancis yang meraih penghargaan tertinggi di Festival Film Cannes ke-61 pada tahun 2008, dan masuk nominasi film berbahasa asing terbaik di Oscar. Film itu merupakan film fiksi dokumenter, yang menggambarkan kehidupan remaja Prancis yang multikultur dengan segala masalahnya. Film ini dibuat berdasarkan kisah nyata seorang guru bahasa Prancis bernama Francois Begaudeau. Francois mengajar di sekolah multietnik yang sebagian besar siswanya kaum imigran dan dari kelas menengah ke bawah. Selama setahun,
Francois meneliti kelasnya dengan mencatat kejadian sehari-hari selama proses belajar berlangsung, membukukannya, dan akhirnya membuatnya menjadi film "Entre les Murs".

Film ini menceritakan mengenai seorang guru bahasa Prancis bernama Francois Marin yang mengajar di kelas tiga SMP di pinggiran kota Paris dengan siswa yang multikultur. Banyak kendala yang dihadapinya selama proses mengajar. Siswa pun mengalami masalah komunikasi dengan guru dan juga dengan sesama siswa.

Film ini mampu menggambarkan interaksi guru dan siswa di sekolah multietnik dan 
masalah-masalahnya sehingga menarik unmk menjadi objek kajian penehrian multikultural maupun dari bidang pendidikan. Hussein (2011) menganalisis film ini unmk melihat bagaimana kehidupan siswa di pinggiran kota Prancis terutama dari sisi budaya, yaitu agama, sistem masyarakat, dan bahasa. PeneUtian tersebut juga melihat sekilas mengenai pendidikan pada siswa yang multikultural di sekolah tersebut, dikaitkan dengan sistem pendidikan negara Prancis itu sendiri.

Penelitian ini akan melihat kondisi pendidikan multikultural berdasarkan film "Entre les Murs", terutama mengenai nilai-niki pendidikan multikulturalnya. Pendidikan multikultural dapat diartikan sebagai pendidikan mengenai keberagaman kebudayaan. Muhaemin el Ma'hady (dalam Mahfud, 2009) berpendapat bahwa pendidikan multikultural adalah pendidikan tentang keberagaman budaya dalam merespon perubahan demografis dan kultural lingkungan masyarakat tertentu, bahkan masyarakat dunia secara global.

Pendidikan multikultural merupakan salah satu pendidikan yang didasari oleh nilai-nilai dan kepercayaan yang demokratis di dalam masyarakat yang' beragam dan di dunia yang bebas. Pendidikan tersebut dapat meningkatkan kompetensi relasi interkultural individu yang berbeda etnis, agama, kelompok dan lain-lain, sehingga meningkatkan perkembangan pribadi dan dapat mencegah berbagai bentuk rasisme. Seperti yang dikatakan Bennett (dalam Institut National de Recherche Pedagogique Service de Veille Scientifique et technologie, 2007):

L'education multiculturelle peut etre considered comme une approche basee sur des valeurs et des croyances democratiques, en affirmant un pluralisme culture/, dans des societes culturellement diverses et un monde interdependant. Ellepermet de developper des competences interculturelles, de favoriser le developpementpersonnel et de lutter contre certaines formes de discrimination comme le racisme

Tilaar (2004) mengungkapkan bahwa dalam program pendidikan multikultural, fokus tidak lagi hanya diarahkan kepada kelompok rasial, agama, dan kultural domain sebagai arus utama. Fokus seperti itu pernah ditekankan pada pendidikan interkultural untuk meningkatkan pemahaman dan toleransi para individu yang berasal dari kelompok minoritas terhadap budaya arus utama yang dominan yang pada akbirnya menyebabkan orang-orang dari kelompok minoritas terintegrasi ke dalam masyarakat arus utama. Pendidikan multikultural merupakan sikap "peduli" dan mau mengerti perbedaan atau politik pengakuan terhadap kelompok minoritas.

Banks (2005) menjelaskan bahwa pendidikan multikultural memiliki lima dimensi yang saling berkaitan, yang dikenal sebagai nilai-nilai pendidikan multikultural. Nilai-nilai pendidikan multikultural tersebut yaitu: (1) integrasi pendidikan, yaitu mengintegrasikan berbagai budaya dan kelompok untuk mengilustrasikan konsep mendasar, generalisasi, dan teori dalam mata pelajaran atau disiplin ilmu; (2) konstruksi ilmu pengetahuan, yaitu memahami implikasi budaya dan sejarah sebuah masyarakat ke dalam sebuah disiplin ilmu atau mata pelajaran; (3) pedagogik kesetaraan antarmanusia, yaitu menyesuaikan metode pengajaran dengan cara belajar siswa dalam rangka memfasilitasi prestasi akademik siswa yang beragam baik dari segi ras, budaya ataupun sosial; (4) pengurangan prasangka, yaitu mengurangi prasangka buruk terhadap budaya lain; dan (5) pemberdayaan kebudayaan sekolah yaitu melatih kelompok untuk berpartisipasi dalam kegiatan olahraga, berinteraksi dengan seluruh staf dan siswa yang berbeda etnis dan ras dalam upaya menciptakan budaya akademik.

Kelima nilai-nilai pendidikan multikultural ini yang akan dianalisis dari film "Entre les Murs". Dalam melakukan analisis terhadap sebuah film, perlu memilih metode yang sesuai dengan fokus analisis atau elemen yang diteliti (Journot, 2002). Terdapat berbagai metode berbeda yang dapat digunakan unmk menganalisis film sesuai dengan film atau elemen apa yang akan diteliti. Lebih lanjut dikatakan oleh Metz (1977), untuk menganalisa film harus memperhatikan apa yang akan diteliti: meneliti bahasa atau meneliti film. Penelitian film berhubungan dengan produksi, misalnya mise en scene, kamera, dan kostum. Sementara, jika meneliti bahasa film berhubungan dengan naratif dan sintagmatik.

Penelitian mengenai bahasa film berkaitan dengan analisis terhadap interaksi timbal balik 
antara penutur atau dialog yang ada dalam film tersebut. Kajian mengenai dialog yang berupa interaksi sering disebut analisis percakapan. Analisis percakapan berfokus pada prinsip-prinsip mengenai serangkaian (tuturan) dalam interaksi sosial, seperti pengorganisasian dan penentuan giliran berbicara, prinsip mendasari strategi pergantian penumr atau adanya mekanisme yang digunakan partisipan untuk mencapai pemahaman (Traverse, 2007). Hal ini menunjukkan bahwa terdapat beberapa konsep utama dalam analisis percakapan, antara lain pasangan tuturan berdekatan [adjancy pair) yaitu sebuah urutan dua ujaran yang berdekatan yang dihasilkan oleh penutur yang berbeda, giliran bicara \{turn-taking\}, dan transisi tempat yang relevan (transition - relevance place) yang merujuk pada berbagai unit seperti konstruksi kalimat, klausa, frasa atau leksis yang dapat digunakan pembicara unmk melakukan giliran bicara (Schiffrin, 1994).

Penggunaan analisis percakapan terhadap film ini sesuai dengan tujuan penelitian ini. Penelitian ini bertujuan unmk mengungkap dan menganalisis nilai-nilai pendidikan multikultural yaitu integrasi pendidikan, konstruksi ilmu pengetahuan, pedagogik kesetaraan antarmanusia, pengurangan prasangka, dan pemberdayaan kebudayaan sekolah yang terdapat di dalam film "Entre les Murs".

\section{METODE}

Metode penelitian ini menggunakan analisis percakapan. Data diperoleh dengan cara melihat dan mendengarkan film serta membaca skenario film. Data penelitian ini adalah berfokus pada dialog, monolog yang mengandung nilai-nilai pendidikan multikultural. Nilai-nilai pendidikan multikultural yang dilihat adalah:

1. Integrasi isi atau content integration

2. Proses konstruksi ilmu pengetahuan atau knowledge construction process

3. Pedagogik kesetaraan antarmanusia atau an equity paedagogy

4. Pengurangan prasangka atau prejudice reduction
5. Pemberdayaan kebudayaan sekolah atau empowering school culture

Langkah awal penelitian ini adalah penentuan adegan film yang dilihat dari latar yaitu tempat atau ruang. Analisis dapat langsung ditentukan karena sudah ditentukan dalam skenario. Jika tidak tersurat, dapat dianalisis melalui hubungan sebab akibat dan kaitan antara satu tokoh dengan lainnya. Setelah itu, adegan yang sudah ada disaring dengan diberi kode atau nomer disesuaikan dengan pertanyaan. Setelah diberi kode, dijelaskan lalu disusun sesuai konten. Adegan kemudian disaring menggunakan analisis percakapan, yaitu disaring dengan menggunakan struktur tuturan yang terdekat, giliran bericara (turn taking), dan transisi tempat yang relevan sehingga mendapatkan nilai-nilai pendidikan multikultural.

Setelah mendapatkan unit-unit percakapan yang mengandung nilai-nilai pendidikan multikultural, unit-unit tersebut diklasifikasikan dan dimasukkan ke dalam tabel nilai-nilai pendidikan multikultural. Pembahasan sudah didiskusikan kepada Profesor Beacco dari Universite, Sorbonne, Paris 3 Apabila terdapat keraguan dalam mengklasifikasi, lihat kembali keterangan yang lebih rinci dari nilai-nilai pendidikan multikultural. Setelah itu, data dicek kembali dan diinterpretasikan.

\section{HASIL}

\section{Pendidikan Multikultural Ditinjau dari Integrasi Pendidikan}

Pada film "Entre Les Murs" terdapat 2 percakapan yang menunjukkan nilai integrasi pendidikan. Percakapan pertama berada di adegan 7 , kerika terjadi diskusi diskusi antara dua guru yang mengajar mata pelajaran yang berbeda, bahasa Prancis dan Sejarah, di awal semester. Keduanya ingin memberikan tugas membaca vang selaras dengan dua mata pelajaran tersebut sehingga mereka berdiskusi mengenai buku apa vang tepat diberikan kepada siswa. Percakapan kedua berada di adegan ke 39, merupakan salah satu adegan akhir di film ini. Francois Marin vang bertindak sebagai wali kelas sekaligus guru bahasa Prancis bertanya mengenai apa yang para 
siswa telah pelajari selama satu semester, tidak hanya mengenai pelajaran bahasa Prancis tetapi juga mengenai pelajaran lain. Ketika para siswa bergantian menjawab pertanyaan tersebut, Francois mendengarkan dan juga menstimulas agar siswa menjawab dan menjelaskan dengan istilah dalam bahasa Prancis yang tepat. Hal ini menunjukkan bahwa Francois mengintegrasikan ilmu dan materi dari berbagai mata'pelajaran lain dalam mempelajari bahasa Prancis.

\section{Pendidikan Multikultural Ditinjau dari Konstruksi Ilmu Pengetahuan}

Pada film "Entre Les Murs" terdapat percakapan yang menunjukkan nilai konstruksi yaitu pada adegan ke 12. Francois meminta Esmeralda membaca buku Anne Frank. Setelahnya, Francois menjelaskan kaitan antara buku tersebut, sejarahnya, dan togas potret diri yang dia berikan pada siswanya. Hal ini menunjukkan bahwa dalam setiap tugas yang diberikan, tercipta konstruksi ilmu pengetahuan yang tidak hanya semata-mata mengajarkan satu hal, tetapi juga mengajarkan makna yang terkandung di dalamnya. Seperti tugas membuat potret diri, Francois menjelaskan bahwa perasaan dari penulis akan mempengaruhi bagaimana hasil tulisannya dan pada akhirnya, mempengaruhi bagaimana orang lain akan melihat mengenai dirinya sendiri.

\section{Pendidikan Multikultural Ditinjau dari Pedagogik Kesetaraan antar Manusia}

Nilai pedagogik kesetaraan antarmanusia cukup banyak ditunjukan dalam film ini, yaitu sebanyak 7 percakapan. Dalam film, Francois sering memberikan kesempatan kepada siswa unmk meningkatkan percaya diri dan memberikan pendidikan yang sama tanpa membedakan etnis, warna kulit dan agama, dengan memuji atau dengan kata-kata yang baik dapat memotivasi siswa. Misalnya pada adegan ke 6 ketika Wei tidak mengerti apa itu makna kata "autrichien", dan ditertawai oleh teman-temannya, terutama Sandra. Francois kemudian menerangkan dan mengucapkan kata-kata yang membuat kepercayaan diri Wei kembali.

\section{Francois}

Eh,Sandra, tu la ramenes pas trop. Quand on ne salt pas ce que signifie "trompeur", on ne donne pas de le^on aux autres. Bon Wei, tu sais ce que c'est I'Autriche?

Hai Sandra, kamu jangan keterlaluan terhadapnya. Ketika orang tidak tahu apa arti "trompeur", kamu jangan mengejek orang lain. Baiklah Wei, kamu tahu apa itu "L'autriche"

Wei

E'Autriche, nonje sais pas Soya tak. tabu apa 'Autrichien"

\section{Sandra}

Tout le monde sait ce que c'est Autrichien" Semua orang tabu apa "Autrichien"

\section{Francois}

En fait, c'est un pays, un tout petit pays. Bon ben franchement, c'est pas la peine de s'esquinter le cerveau la-dessus, pane qu'en gros c'est un pays qui $n^{\prime}$ a aucune importance dans le monde, et pas meme en Europe. Est-ce que quelqu'un connait un Autrichien celebre?Voila, j'vous le disais. Si une bombe rayait I'Autriche de la carte, personne s'en rendrait compte.

Kami mengerti. Kau tak tahu "misleading", jadi kau tak seharusnya malu. "orang Austria" bukan kata yang penting, Wei. Ia menunjuk pada seseorang yang berasal dari Austria yang merupakan negara kecil. Kita bisa hidup tanpa kata itu.

Francois juga menyemangati dan menjadikan Souleymane bangga akan dirinya. Souleymane termasuk siswa yang kurang pintar dan jarang mengungkapkan diri di kelas. Ketika dia diminta membuat potret diri, dia merasa tidak bisa. Oleh karena itu, Francois memberi motivasi dengan mengatakan Souleyman pasti bisa. Lalu Francois mencetak dan menempelkan pekerjaan Souleymane di dinding agar temannya dapat melihat hasil kerja Souleymane. Menurut Francois, pekerjaan Souleymane sangat baik dan dapat dicontoh oleh siswa lainnya. Souleymane awalnya menolak karena takut hanya akan 
dibodohi, namun pada akhirnya pun tersenyum malu dan bangga.

\section{Pendidikan Multikultural ditinjau dari Pengurangan Prasangka}

Nilai pengurangan prasangka merupakan nilai yang paling banyak muncul dalam film, yaitu sebanyak 15 percakapan, baik yang menunjukkan prasangka yang masih tinggi, maupun usaha unmk mengurangi prasangka tersebut. Pada film ini banyak prasangka negatif yang ada pada pikiran guru dan siswa. Sebanyak 12 percakapan yang menyiratkan adanya prasangka negatif, baik antar siswa maupun antara guru dan siswa.

Beberapa percakapan menunjukkan adanya prasangka negatif siswa kepada gurunya. Contohnya, ketika Francois mengajarkan gramatikal di kelas dan mengambil contoh mengambil nama Bill. Kemudian dua siswi yang berasal dari Afrika memprotes mengapa mengambil contoh nama orang Amerika, mengapa bukan mengambil nama dari lingkungannya, misalnya Aisyata. Kedua siswi memiliki anggapan bahwa Francois tidak menghargai mereka dan rasnya.

Dalam film ini, prasangka negatif muncul antar siswa tercipta karena adanya perdebatan mengenai sepakbola. Tiap siswa membela tim negara asalnya masing-masing, seperti Mali, Karibia dan Maroko. Mereka saling ejek antar ras sehingga berujung pada perdebatan antara siswa yang berasal dari Mali dan siswa yang berasal dari Karibia. Hal itu menunjukkan bahwa para siswa masih memegang jati < Jirinya sesuai dengan daerah asalnya. Mereka juga masih menganggap bahwa lawan bicaranya bukanlah berasal dari daerah yang sama, walaupun saat ini mereka sama-sama tinggal di Prancis. Oleh karena itu, ejekan yang menyinggung daerah asal atau ras masing-masing dapat menyinggung perasaan lawan bicara dan dapat berujung pada perkelahian.

Prasangka negatif juga terjadi pada guru. Pada awal tahun ajar, seorang guru lama menjelaskan kepada seorang guru baru mengenai setiap siswa di kelasnya. Namun, guru tersebut hanya memberikan daftar nama siswa dan menyebutkan bahwa siswa yang itu baik, sementara beberapa siswa lainnya tidak baik. Hal ini menunjukkan adanya penanaman prasangka pada diri guru baru yang dilakukan oleh guru lama. Dengan adanya penanaman prasangka itu, bisa menimbulkan prasangka negatif guru baru kepada siswa, bahkan sebelum pembelajaran dimulai.

Salah satu prasangka negatif dari guru juga terlihat pada diri Francois. Ketika Francois sedang menjelaskan pelajaran, beberapa siswa kemudian bertanya mengenai hal di luar pelajaran. Pertanyaan yang mereka ajukan berkaitan dengan hasil rapat yang dihadiri oleh Esmeralda dan Louis. Hal ini menyebabkan Francois menyatakan kekesalan dan kekecewaannya pada perwakilan kelas yaitu Esmeralda dan Louis yang mcnceritakan hasil rapat serta bertingkahlaku tidak sopan ketika rapat. Francois kemudian menyebutkan bahwa ketika rapat, mereka berdua bertingkah laku seperti pelacur, karena tertawatawa sendiri dan melakukan hal-hal yang kurang sopan. Hal itu menunjukkan bahwa guru itu memiliki prasangka negatif terhadap perilaku negatif siswanya, yang kemudian diasosiasikan dengan perilaku negatif seorang pelacur.

\section{Francois}

Dites donne toutes les deux, vous ave^ choisi d'etre deleguees pour representer vos copains, on juste pour foutre le bordel en racontant $n$ 'importe quoi? Louise On a fait ce qu'on doit faire dans les conseils, c'est tout.

\section{Francois}

D'ailleurs j'ai pas en $V$ occasion de vous le dire, mais franchement, tout le long $d u$ conseil,j'etais tres mal pour vous. Ce n' etait ni le moment ni le lieu pour ricaner comme fa.

\section{Esmeralda}

Serieux, ta derangeait pas.

\section{Francois}

Ah si, fa derangeait... Je $m$ 'excuse mais moi, rire comme fa en plein conseil, c'est c'que j'appelle une attitude de petasse. Khoumba

$C^{\prime}$ est bon , $f a$ se fait pas de traiter ses e'leves, m'sieur.

\section{Francois}

On dit pas traiter, on dit insulter.

\section{Esmeralda}

C'est pas la peine de nous insulter de petasse. 
Penggunaan istilah 'pelacur' kemudian berdampak besar pada para siswa, karena para siswa kurang mampu membedakan 'bertingkah seperti pelacur' dengan menyebut seseorang sebagai pelacur. Ketika Francois berusaha menjelaskan hal tersebut, para siswa sudah tidak percaya padanya. Hal ini menunjukkan bahwa prasangka dapat memberikan dampak negatif yang sangat besar.

Secara umum, pengajar sudah memberikan kesempatan pada semua siswa dari kelompok etnik yang berbeda dalam kegiatan pengajaran. Namun, di dalam film kurang terlihat adanya usaha pengajar dalam pengurangan prasangka terhadap siswa dalam interaksinya. Di sisi lain, siswa menunjukkan beberapa interaksi interpersonal antaretnis yang menunjukkan adanya usaha pengurangan prasangka, seperti misalnya tanpa berpikir panjang siswa langsung membantu ketika ada temannya yang mendapat kesulitan, yaitu ketika pulpennya bocor dan membutuhkan tisu. Demikian pula ketika Souleymane, yang berasal dari Mali, terancam dikeluarkan, semua temannya menemui gurunya dan berusaha menolongnya. Bahkan termasuk Carl yang berasal dari Karibia, yang sebelumnya terlibat pertengkaran dengan Souleymane.

\section{Pendidikan Multikultural Ditinjau dari Pemberdayaan Kebudayaan Sekolah}

Dalam film "Entre les Murs", ditunjukkan bahwa sekolah sudah menunjukkan beberapa budaya sekolah yang berusaha memberdayakan para siswa dari kelompok budaya yang berbeda. Terdapat 7 percakapan yang mengandung nilai pemberdayaan kebudayaan sekolah.

Pemberdayaan kebudayaan sekolah terlihat ketika membuat kebijakan unmk kepentingan bersama. Dalam menentukan suatu kebijakan, selalu didiskusikan dengan semua orang yang terlibat, baik kepala sekolah, perangkat sekolah, wakil orang ma, dan guru. Kebijakan dibahas baik dari segi akademis siswa seperti penggunaan sistem poin dan sanksi sebagai penilaian akademis maupun dari segi kesejahteraan staf yaitu ketersediaan mesin fotokopi.

Selain pembuatan kebijakan sekolah, beberapa program sekolah lain juga mengikutsertakan semua pihak, baik kepala sekolah, guru, wakil orang ma, bahkan wakil siswa. Contohnya ialah penilaian siswa sebelum kenaikan kelas. Rapat penilaian siswa menyertakan kepala sekolah, guru, dua siswa yang berpretasi, dan kornite orang ma. Rapat penilaian tidak hanya memperhitungkan nilai akademis, tetapi juga sikap dan kedisiplinan. Dalam rapat itu, semua wakil siswa memiliki hak unmk berbicara dan mengungkapkan pendapat, termasuk siswa. Rapat lainnya yang juga melibatkan perangkat sekolah, perwakilan orangtua, dan perwakilan siswa adalah "diciplinary hearing" atau forum agar suatu masalah yang melibatkan seorang siswa dapat dilihat dari kedua sisi dan dapat memberikan hasil yang objektif.

Program unmk mengembangkan interaksi interpersonal antara kepala sekolah, guru dan siswa juga dilakukan. Di akhir sekolah, sebelum libur, seluruh perangkat sekolah dan siswa pria bermain bola bersama sedangkan siswi menonton dan menjadi suporter teman-temannya. Programprogram yang disediakan oleh sekolah ini menunjukkan bahwa sekolah sebagai instansi serta staff pengajar telah melakukan usaha-usaha untuk menciptakan budaya sekolah yang baik dalam pendidikan multikultural.

\section{PEMBAHASAN}

Menurut Banks, terdapat lima dimensi pendidikan multikultural yang saling berkaitan atau nilai-nilai pendidikan multikultural yaitu integrasi pendidikan, konstruksi ilmu pengetahuan, pedagogik kesetaraan antarmanusia, pengurangan prasangka, dan pemberdayaan kebudayaan sekolah. Kelima nilai pendidikan multikultural ini terlihat dalam film "Entre les Murs".

Nilai integrasi pendidikan menunjukkan guru menggunakan contoh dan isi pengajaran dari berbagai budaya dan kelompok unmk mengilustrasikan konsep dasar, prinsip dan teori dari mata pelajaran disiplin ilmu. Integrasi dari berbagai budaya dan etnis lebih dimungkinkan terjadi pada beberapa mata pelajaran dibandingkan dengan yang lainnya. Dalam film 
itu, dapat dilihat suasana akademis dan nilai integrasi pendidikan. Guru sejarah bertanya kepada guru bahasa Prancis tentang buku bacaan yang diberikan kepada siswa. Guru sejarah memberikan materi yang berisi berbagai budaya dan sejarah akan dilanjutkan dengan bacaan susastra tentang cerita yang berlatar sejarah dan budaya. Oleh karena itu, mereka berdiskusi tentang bacaan yang diberikan kepada mata pelajaran sejarah dan pelajaran kesusastraan. Mereka berusaha unmk menggunakan bacaan atau buku yang berhubungan agar antara pelajaran sejarah dan bahasa terjadi proses belajar yang berkesinambungan.

Konstruksi ilmu pengetahuan adalah konstruksi ' ilmu unmk memahami implikasi budaya ke dalam suatu disiplin ilmu (mata pelajaran) mengenai sejarah perkembangan masyarakat Barat dan perlakuannya serta reaksi kelompok etnis lainnya. Sejarah berisi hal-hal yang positif ataupun negatif yang perlu diketahui oleh siswa di dalam upaya mengerti kondisi masyarakatnya dewasa ini. Konstruksi ilmu pengetahuan menunjukkan bagaimana guru membantu siswa unmk memahami, mempelajari dan menentukan bagaimana asumsi budaya yang implisit yaitu referensi, prespektif, bias dapat mempengaruhi terbentuknya ilmu pengetahuan. Pada film itu terlihat ketika di dalam kelas, guru ingin siswanya dapat membuat potret diri dengan cara mengungkapkannya dengan kata-kata. Guru mengambil contoh buku harian dari seseorang yang bernama Anne Franc sebagai buku bacaan wajib. Anne berumur hampir sama dengan siswa di kelas dan kebangsaan Jerman. Buku harian itu sangat terkenal dan menceritakan pengalaman dan potret diri Anne ketika dia dalam keadaan perang, dia seorang diri dan berusaha keluar dari situasi sulit tersebut. Cara Anne mengungkapkan ditinya dia dan bagaimana keadaan dia dengan bahasa yang sederhana tetapi sangat menarik. Oleh karena itu, siswa diminta unmk membuat potret diri, yaitu menjelaskan dirinya sendiri dilihat dari berbagai sisi, seperti kebiasaan seharihari, nilai-nilai yang dianut serta kondisi sosial dan budayanya. Siswa hendaklah memiliki pengetahuan dari mana saja dan dari siapapun juga. Dalam hal itu, materi ajar harus berkesinambungan dengan cerita, realitas sosial dan kondisi keberadaan kelompok etnis dan budaya tertentu.

Pendidikan kesetaraan antarmanusia menurut Banks adalah penyesuaian metode pengajaran dengan cara siswa belajar dalam memfasilitasi prestasi akademik siswa yang beragam baik, dari segi ras, budaya maupun sosial. Pedagogik kesetaraan terjadi ketika guru mengubah cara pengajarannya, yaitu dengan pengajaran yang bervariasi sehingga dapat menfasilitasi pencapaian akademis setiapi siswa yang berasal dari ras, budaya, jenis kelamin, dan kelas sosial yang berbeda. Oleh karena itu, guru harus memperhatikan setiap siswa karena setiap siswa memiliki keunikan sehingga penanganannya juga berbeda dari satu siswa ke siswa lain. Dalam film ini guru sering memberikan kesempatan kepada siswa unmk meningkatkan percaya diri dan memberikan pendidikan yang sama tanpa membedakan etnis, warna kulit dan agama, dengan memuji atau dengan kata-kata yang baik dapat memotivasi siswa. Misalnya ketika Wei seorang siswa yang berasal dari Cina tidak mengerti apa itu makna kata autrichien, dan ditertawai temannya. Guru kemudian menerangkan dan mengucapkan kata-kata yang membuat percayaa diri Wei kembali. Gurunya juga menyemangati dan menjadikan Souleymane bangga akan dirinya. Souleymane termasuk siswa yang kurang pintar dan jarang mengungkapkan diri di kelas. Sehingga ketika dia diminta membuat potret diri, dia merasa tidak bisa. Oleh karena itu, gurunya memberi motivasi dengan mengatakan Souleyman pasti bisa. Gurunya kemudian memperhatikan bahwa Souleymane tertarik dengan komputer dan foto sehingga guru memuji hasil foto yang dibuat Souleyman dan mengajarkan beberapa hal di komputer yang dapat memperindah hasil fotonya, yaitu dengan menambahkan sedikit kata-kata pengungkap diri di bawah foto tersebut. Lalu gurunya mencetak dan menempelkan pekerjaan Souleymane di dinding agar temannya bisa melihat hasil kerja Souleymane. Hal ini membuat Souleymane merasa bangga terhadap dirinya sendiri dan lebih percaya diri.

Pengurangan prasangka adalah proses mengurangi prasangka buruk terhadap budaya lain sehingga maumpu bersikap positif atau netral 
terhadap budaya lain. Namun dalam film ini banyak prasangka negatif yang ada pada pikiran guru dan siswa. Banyak adegan yang menunjukkan adanya prasangka negatif siswa kepada gurunya, siswa dengan siswa, dan guru kepada siswanya.

Dengan banyaknya prasangka negatif dalam diri siswa dan berdampak besar, perlu dilihat apakah sudah ada usaha pengajar untuk mengurangi prasangka, sebagai salah satu nilai pendidikan multikulturahsme. Pengurangan prasangka berarti pengajaran dan aktivitas yang dilakukan guru membantu siswa mengembangkan sikap positif terhadap ras, etnik, dan kelompok budaya yang berbeda. Secara umum, pengajaran yang guru memberikan kesempatan pada semua siswa dari kelompok etnik yang berbeda menunjukkan adanya usaha pengurangan prasangka. Guru juga mampu menerima masukan dan menerima beberapa keinginan siswa, seperti penggunaan nama dalam kalrmat yang lebih sesuai dengan kondisi kelompok etnis di kelas. Namun, selain itu, dalam film im kurang terlihat adanya usaha pengajar dalam pengurangan prasangka terhadap siswa. Beberapa kali pengajar terlihat masih memiliki prasangka negatif yang tinggi.

Di sisi lain, walaupun banyak prasangka buruk antar siswa ataupun siswa terhadap guru, siswa menunjukkan beberapa interaksi interpersonal antaretnis yang menunjukkan adanya usaha pengurangan prasangka. Misalnya tanpa berpikir panjang siswa langsung membantu ketika ada temannya yang mendapat kesulitan, yaim ketika pulpennya bocor dan membutuhkan tisu. Demikian pula ketika Souleymane, yang berasal dari Mali, terancam dikeluarkan, semua temannya menemui gurunya dan berusaha menolongnya. Bahkan termasuk Carl yang berasal dari Karibia, yang sebelumnya terlibat pertengkaran dengan Souleymane.

Pemberdayaan kebudayaan sekolah adalah proses melatih kelompok unmk berpartisipasi dalam kegiatan berolahraga, berinteraksi dengan seluruh staf dan siswa yang berbeda etnis dan ras dalam menciptakan budaya akademis. Dengan demikian, beberapa variabel yang diperiksa unmk menentukan apakah budaya sekolah sudah memberdayakan siswa dari kelompok budaya yang berbeda, antara lain berpartisipasi dalam berolah raga, pencapaian akademis yang tidak merata, penerimaan mahasiswa yang tidak merata, dan interaksi antara staf dan siswa yang berbeda etnis. Dalam film itu, pemberdayaan kebudayaan sekolah banyak terlihat di ruang guru, yaitu hubungan antar guru yang akrab. Guru yang memiliki masalah dapat meminta saran guru lain, kemudian berdiskusi. Keputusan mengenai langkah apa yang periu diambil untuk para siswa juga memperrimbangan pandangan guru lain yang juga mengajar siswa itu sehingga meminimaliskan keputusan yang subjektif dan berat sebelah. Hal itu merupakan contoh pemberdayaan kebudayaan sekolah karena kebudayaan sekolah dimulai dari interaksi dengan staf dalam upaya menciptakan budaya akademis.

Pemberdayaan kebudayaan sekolah juga terlihat ketika membuat kebijakan unmk kepentingan bersama. Dalam menentukan suatu kebijakan, selalu didiskusikan dengan semua orang yang terlibat, baik kepala sekolah, perangkat sekolah, wakil orang ma, dan guru. Selain pembuatan kebijakan sekolah, beberapa program sekolah lain seperti rapat penilaian siswa dan disciplinary hearing juga mengikutsertakan semua pihak, baik kepala sekolah, guru, wakil orang ma, bahkan wakil siswa. Hal itu menunjukkan bahwa melalui programnya, sekolah membuat adanya interaksi antara seluruh staf dan siswa yang berbeda etnis dan ras dalam upaya menciptakan budaya akademik. Program untuk mengembangkan interaksi interpersonal antara kepala sekolah, guru dan siswa juga dilakukan. Di akhir sekolah, sebelum libur, seluruh perangkat sekolah dan siswa pria bermain bola bersama scdangkan siswi menonton dan menjadi suporter teman-temannya. Hal ini sesuai dengan teori Banks yang menunjukkan bahwa melalui partisipasi olahraga dapat menciptakan pemberdayaan kebudayaan sekolah yang baik. Selain itu, hal-hal ini juga sesuai dengan teori Banks yang menunjukkan bahwa pemberdayaan kebudayaan sekolah merupakan muara dari keempat pendekatan lain karena sekolah merupakan motor penggerak di dalam perubahan struktur masyarakat yang timpang karena kemiskinan ataupun tersisihkan di dalam budaya arus utama "mainstream" masyarakat. 


\section{SIMPULAN}

Berdasarkan hasil analisis, ditemukan bahwa pengurangan prasangka merupakan nilai yang paling banyak ditemukan. Namun, dari lima belas percakapan yang mengandung nilai pengurangan prasangka, sebagian di antaranya merupakan bentuk prasangka negatif. Hal ini menunjukkan bahwa dalam film "Entre les Murs", usaha pengurangan prasangka dari guru maupun siswa masih mendapat hambatan dari prasangka negatif yang masih ada pada sebagian guru dan siswa.

Nilai pedagogik kesetaraan manusia juga merupakan nilai yang banyak ditemukan dalam film. Nilai pemberdayaan kebudayaan sekolah juga banyak ditemukan dalam film, hampir sebanyak nilai pedagogik kesetaraan manusia. Hal ini menunjukkan bahwa sekolah sebagai instansi serta staff pengajar telah melakukan usaha-usaha unmk menciptakan budaya sekolah yang baik dalam pendidikan multikultural. Sementara, nilai integrasi pendidikan dan nilai konstruksi ilmu pengetahuan juga muncul namun tidak sebanyak ketiga nilai pendidikan multikultural lainnya.

Berdasarkan film "Entre les Murs", kunci keberhasilan dari pendidikan multikultural terletak pada figur guru yang yang mampu mengurangi prasangka negatif dan memberikan pendidikan yang sama kepada para siswa. Hal ini juga harus didukung oleh sistem dan kebudayaan sekolah. Sistem dan kebudayaan sekolah diharapkan dapat mendukung pendidikan multikultural dengan melibatkan seluruh komponen sekolah, wali murid, dan siswa dalam program-programnya.

Diharapkan dengan adanya penelitian ini, pengajar dapat mengetahui dan menerapkan nilai pengurangan prasangka dan pendidikan kesetaraan antarmanusia dalam pengajarannya dan interaksinya dengan siswa. Pengajar diharapkan tidak memiliki prasangka negatif kepada siswanya sejak awal, karena dapat mempengaruhi persepsi pengajar selama kegiatan belajar mengajar berlangsung. Pengajar juga harus memperhatikan setiap siswa, misalnya latar belakang budaya nya dan pribadinya, sehingga mengetahui cara pengajaran yang tepat kepada setiap siswa karena setiap siswa membutuhkan cara pengajaran yang berbeda-beda. Pengajar juga harus memperhatikan isi materi ajar. Misalnya, pada pengajar bahasa Prancis, di Indonesia juga perlu memperhatikan dan mengaitkan dengan sejarah, budaya Prancis dan budaya Indonesia, dan lain-lain.

Terlepas dari ketercapaian hasil penelitian ini, penulis menyadari keterbatasan yang dihadapi dalam proses penelitian seperti proses verifikasi data. Verifikasi data penelitian dilakukan oleh penulis bekerja sama dengan seorang dosen Prancis dari Universitas Bina Nusantara. Padahal verifikasi data penelitian ini akan lebih layak apa bila dilakukan oleh penutur ahli bahasa Prancis yang sekaligus berkompeten dalam bidang multikultural.

Selain itu, implikasi penelitian ini adalah saran kepada pihak sekolah, karena semua perangkat akademik juga harus mendukung pengajaran. Sekolah harus menumbuhkan budaya yang mendukung para siswa yang berbeda budayanya unmk dapat berkembang. Misalnya, dengan melibatkan seluruh komponen sekolah, baik dari kepala sekolah, staff pengajar, staff non akademik, wali murid, dan siswa itu sendiri dalam berbagai kegiatan. Kegiatan ini dapat berupa kegiatan yang berhubungan dengan akademik siswa seperti rapat guru dan orangtua murid, maupun kegiatan non akademik seperti olahraga bersama.

Selain itu, penelitian ini juga menunjukkan bahwa para siswa juga memegang peranan aktif dalam menimbulkan suasana belajar mengajar yang kondusif bagi pendidikan multikultural. Siswa diharapkan dapat menghilangkan prasangka negatif pada guru maupun siswa lainnya. Sehingga, proses pengajaran dapat berlangsung lebih optimal.

Penelitian ini dapat diteruskan dengan penelitian lanjutan, misalnya, mengenai kekerasan berbahasa (yiolance verbale) dalam film Entre les Murs. Di film tersebut banyak ungkapanungkapan kasar yang terlontar baik dari siswa maupun dari guru. Kekerasan berbahasa dapat terjadi tidak hanya karena seseorang pemarah atau yang bersikap kasar, tetapi karena ketidaktahuan penggunaan kata-kata tersebut. Oleh karena, itu interaksi dalam berbahasa membutuhkan 
pengetahuan komunikasi budaya. Hal itu sangat menarik karena sekarang ini masyarakat dunia, baik di Prancis maupun di Indonesia adalah masyarakat multietnik, multiagama dan multikultural.

Penelitian ini juga menghasilkan rekomendasi pada sistem pendidikan Indonesia. Sistem pendidikan saat ini dianggap belum sepenuhnya menyediakan keragaman etnis, salah satunya ditandai dengan adanya pelajaran bahasa daerah, pelajaran kesenian dan prakarya terpisah. Seharusnya dalam pelajaran bahasa daerah tidak hanya terbatas pada pengajaran bahasanya saja, melainkan nilai-nilai budaya, norma, dan tradisi juga harus berintegrasi.

\section{DAFTAR PUSTAKA}

Aumont, Jacques dan Marie, Michael. 1988, L Analyse des Films. Paris: Nathan.

Banks, A James. 2005. Multicultural Education : Issues and ^respective. New Yersey: John Wiley \& Sons Inc.

Delors, Jacques. 1996. Learning: The Treasure Within. Prancis: UNESCO

Denzin Norman K, Lincoln Yvonna S. 2009. Handbook of Qualitative Research Yogyakarta: Pustaka Jakarta.

Emzir. 2010. Analisis Data, Metodologi Penelitian Kualitatif. Jakarta: Raja Grafindo Persada.
Endraswara Suwardi. 2008. Metodologi Penelitian Sastra. Jakarta: Buku Kita

Eriyanto. 2005. Analisis Wacana, pengantar analisis teks media, Yogyakarta: PT. LKiS Pelangi Aksara.

H.A.R Tilaar. 2004. Multikuturalisme, Jakarta : Grasindo.

Hussein, Keith. 2011. Beur culture as reexploration of the enlightenment in entre les murs (The class). Transitions: Journal of FrancoIberian Studies, 7, 53-70.

Journot, Marie-Therese. 2002. Le Vocabulaire du Cinema, Paris: Nathan/VUEF.

Koentjaraningrat. 2009. Pengantar llmu Antropologi Jakarta: Rineka Cipta.

Kramsch Claire. 1998. Language and Culture. Oxford: Oxford University Press.

Mahfud Choirul. 2009. Pendidikan Multikultural. Yogyakarta: Pustaka Pelajar.

Metz Christian. 1977. , Langage et Cinema. Paris: Editions Albatros.

Schiffrin Deborah. 1994. Approach to Discourse. Cambridge: Blackwell.

Titscher, Stefan, Mayer Michel, Wodak Ruth, dan Vetter Eva. 2009. Metode Analisis Teks dan Wacana. Yogyakarta:Pustaka Pelajar.

Traverse Veronique. 2007. L'Analyse des Conversations. Paris: Armad Colin. 